\title{
INFORMAL YOUTH ASSOCIATIONS AS A BUSINESS REALITY
}

\author{
Tatiana Kolomoets' ${ }^{1}$, Pavel Liutikov ${ }^{2}$, Mikhail Larkin ${ }^{3}$ \\ Zaporizhzhia National University, Ukraine
}

\begin{abstract}
Informal youth environment is not only an integral part of today's reality but also a complex multi-vector problem. The purpose of the article is to study business processes as one of the aspects of the activity of individual youth informal associations. Methodology. In the process of work on the article, scientific literature devoted to youth informal associations is analysed. In addition, such theoretical methods as synthesis, comparison, classification are used. The empirical basis for the study is the survey of 1668 representatives of various youth informal groups in 7 cities of Ukraine (Kyiv, Kharkiv, Odesa, Dnipro, Zaporizhzhia, Lviv, Kherson) during 2016-2017. A special questionnaire was developed. Conclusions. On the basis of the analysis of the survey results, informal associations are divided into three groups: youth informal associations, on which people earn (skinheads and hipsters); youth informal associations that earn (freaks, suicidal groups in social networks); youth informal associations, on which people earn and that earn (anime fans, gamers, bikers, football fans). Features of their consumer and business opportunities in Ukraine are revealed. It is concluded that the "life activity" of informal communities is predetermined not only by some ideas, views, moods, way of life but also by business opportunities and opportunities to make a profit. The originality of the work is that for the first time since Ukraine gained independence, youth informal groups are seen as a platform for engaging in entrepreneurial activities. Practical significance. The results of the study can be used to further study of various aspects of the youth informal environment. In particular, in the context of combating illegal business activities, tax evasion.
\end{abstract}

Key words: youth, informal, consumption, business, earnings.

JEL Classification: D31, J13, L26, M21

\section{Introduction}

Probably, the eternal problem of any society, the state is the education of young people. Each new generation is its own world, its own interests, fears, experiences, its understanding of reality and the place of a human in it. And here one cannot help recalling the words of S. Maugham from the novel "Of Human Bondage": "It is an illusion that youth is happy, an illusion of those who have lost it; but the young know they are wretched for they are full of the truthless ideal which have been instilled into them, and each time they come in contact with the real, they are bruised and wounded. It looks as if they were victims of a conspiracy; for the books they read, ideal by the necessity of selection, and the conversation of their elders, who look back upon the past through a rosy haze of forgetfulness, prepare them for an unreal life. They must discover for themselves that all they have read and all they have been told are lies, lies, lies; and each discovery is another nail driven into the body on the cross of life" (Maugham, 2010).
The XX century has shown, or rather illustrated, that a disparaging attitude towards the social challenges thrown down to young people can lead to the emergence of various youth informal formations, movements that seek attention and perception from the greater part of society as by the commission of illegal actions (football fans, neo-Nazis, radicals, anarchists, religious fanatics, etc.), and propaganda of a certain ideology, ideas, way of life, which do not contain an element of wrongfulness (hipsters, freaks, anime fans, gamers, and others). An informal person is an attempt to show one's personality, to tell everyone else, the so-called "faceless mass": "I am a person," to challenge the world with its endless everyday routine and build all in one line (Rybakova, Lizunova, 2016).

To date, a number of attempts have been made to study youth informal formations, most of which have been implemented in the context of political (Boiko, 2001; Soroka, 2006; Vasilchuk, 2016); historical (Blyzniuk, 2010); psycho-pedagogical (Bashkatov, 2002; Lisovets,

\footnotetext{
Corresponding author:

${ }^{1}$ Department of Administrative and Commercial Law, Zaporizhzhia National University.

E-mail: t deputy@ukr.net

${ }^{2}$ Department of Administrative and Commercial Law, Zaporizhzhia National University.

E-mail: lyutikovp@gmail.com

${ }^{3}$ Department of Criminal Law and Justice, Zaporizhzhia National University.

E-mail: malark777@ukr.net
} 
2011), philosophical (Levikova, 2002), legal (Ershov, 2006; Gilinskii, 2010; Boiarov, 2014) paradigms. It should be noted that a huge layer of information on informal youth is on the Internet. However, the economic underpinnings of the existence of informal youth groups remain little investigated. After all, the informal environment is a huge and business space.

The purpose of the article is to study business processes as one of the aspects of the activity of individual youth informal associations.

The empirical basis of the survey was the survey of 1668 representatives of various youth informal groups in 7 cities of Ukraine (Kyiv, Kharkiv, Odesa, Dnipro, Zaporizhzhia, Lviv, Kherson) in 2016-2017 (Figure 1), which made it possible to divide youth informal associations from the point of view of business opportunities, the possibility of making profit in three groups:

1) youth informal associations, on which people earn;

2) youth informal associations that earn;

3) youth informal associations, on which people earn, and that earn.

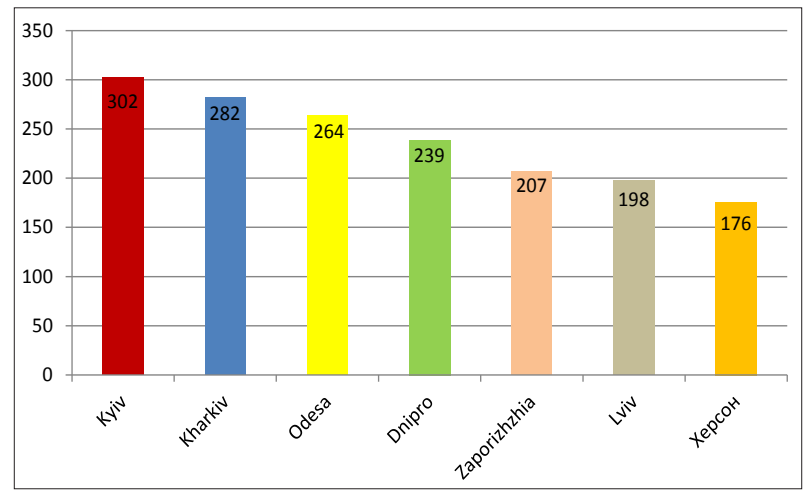

Fig. 1. Questioning of members of youth informal associations (2016-2017)

Now we consider it necessary to characterize each of the selected types on the basis of the studied practical material.

\section{Youth informal associations, on which people earn}

These include skinheads and hipsters.

Skinheads do not try to profit from their way of life, ideas, views. They are in fact consumers of their ideology. They spend money on purchasing clothes, footwear of certain brands (for example, Dr. Martens, Ben Sherman, Fred Perry). A relatively large percentage of skinheads in Ukraine (approximately 70\%) are active football fans and purchase for their own money tickets for matches of their favourite football club, club attributes (scarves, hats), pay for tickets for away matches of the club.

If we draw parallels with the skin movement in England, it should be noted that the Ukrainian skinheads, so to speak, are less "traditional" than their ancestors. In England - this is not just a movement, a way of life, but in fact, its mini-society and the economic factor is important here. This is clearly shown in the book of John King (King, 2010). The life of the main characters consists of everything that belongs to the family of skinheads, their like-minded friends: a taxi company, a nightclub and the like; there is a kind of "internal financial turnover" (Fig. 2).

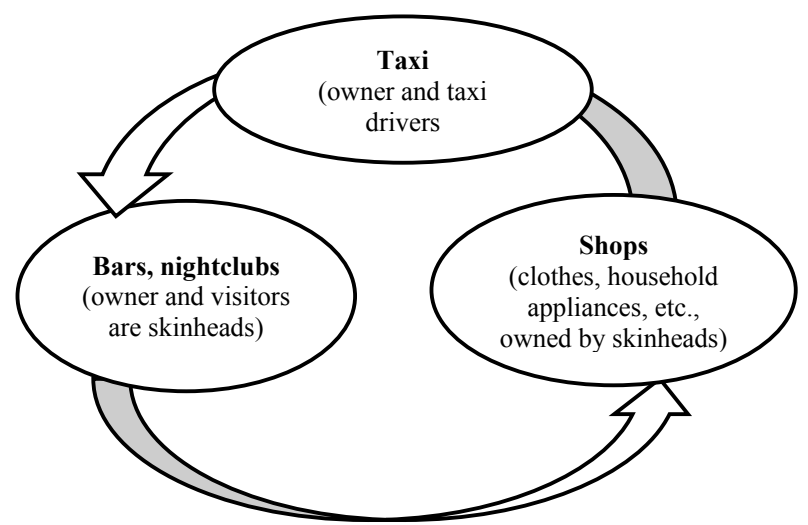

Fig. 2. "Internal financial turnover"

in the skinhead environment

In Ukrainian realities, skinheads are simple consumers of their own worldviews. This can be also said about hipsters - the consumption industry: special brands of clothing (Cheap Monday, Bershka, American Apparel, etc.), magazines (Kinfolk, Vice, etc.), only Moleskine notebooks. Special places of recreation: coffee houses ("Sweeter", "In the mood" - Kharkiv), bars ("Pod Asfaltom Pliazh" ("Under Asphalt Beach"), "Gnezdo bar" - Kyiv). Hipsters are victims of fashion and advertising, so they immediately buy everything new and modern from the preferred brands.

\section{Youth informal associations that earn}

These are: freaks, groups of suicidal character in social networks.

Frick - not only a person who is distinguished for his extraordinary, shocking, but also often a real opportunity to self-enrich. Freaks receive fees for participating in $\mathrm{TV}$ projects, advertising, working as fashion designers, designers, photographers.

The absolutely new product of reality is suicidal groups in social networks ("Blue Whale", "Red Owl", etc.). The purpose of creating such informal communities is to get profit from:

- views of suicidal videos;

- blackmail for the removal of offensive comments, which were specially written before (there may be hundreds or even thousands);

- for leaving in peace (before this, threats to life and health are regularly carried out, blackmail of a group member and his or her close relatives). 


\section{Youth informal associations that earn and on which people earn}

Such, as a result of the conducted research, were: anime fans, gamers, bikers, football fans.

Today we can safely say that anime is one of the most successful global business projects. Anime is quite an expensive hobby. Its fans spend money on sewing costly costumes, participating in festivals (for example, in Odesa, Kharkiv, Dnipro). However, anime is also an opportunity to earn on that tailoring and selling clothes, the design of anime characters, organizing and holding festivals, translation and voice over of serials from Japanese and other languages. Anime stores are open in Kyiv, Kharkiv, Dnipro, Lviv, Zaporizhzhia.

Gamers are a special category of people for whom computer games have ceased to be just entertainment, but have become the meaning of life. The price of a gaming computer can go up to several thousand euros, while it is necessary to constantly improve it and replace individual devices. But gamers have a lot of opportunities for earning. For example:

1) as players (team players)

2) a gamer can sell his broadcasts;

3) advertisers can sponsor a gamer;

4) a gamer after the end of his career can become a coach, analyst, manager of the team;

5) as a developer of computer games;

6) at the rates;

7) on trading;

8) as account boosters;

9) by providing services in games;

10) at the dealership, etc.

Bikers are informal communities of members, united by a love of motorcycles and everything connected with them, including the way of life.

Representatives of the bike movement, according to the results of the survey, spend about $50 \%$ of their earnings on everything related to motorcycles (buying, repairing motorcycles, buying spare parts, paying for repair services), buying clothes, participating in motor exercises, membership fees in biker clubs and so on.

Of course, bikers have the opportunity to earn money on their way of life. It includes:

- services for repair and restoration of motor vehicles;

- tailoring and sales of leather clothes and shoes;

- organization and holding of motor festivals, runs;
- quite often bikers are owners of restaurants, tattoo parlours.

Football fans. Football has long ceased to be just a sporting event. Sufficiently capacious about modern football said the famous Italian coach Arrigo Sacchi: "Football is the most important thing of all unimportant things."

And an integral part of it is football fans. They are direct consumers of the football industry. So, it can be:

1) purchase of tickets (including football season passes), football tours;

2) purchase of sportswear, goods with the symbols of their favourite club;

3) purchase of certain brands of clothing (for example, Stone Island, Burberry, Merc London, Lacoste);

4) pay for paid television.

5) visits to pubs, sports bars.

According to our information, some football fans can spend up to $90 \%$ of their earnings on their "football life".

Fans can earn money due to their hobby as follows:

- rates;

- participation in promotions held by football clubs;

- resale of tickets for football matches;

- participation in political actions, raider seizures.

\section{Conclusions}

Emerged initially as "groups of protest", modern informal associations now represent a complex social product. We made an attempt, based on empirical material, to consider only one of the sides of informalitya business component that allowed:

1. Divide informal associations into three groups: - youth informal associations, on which people earn; - youth informal associations that earn;

- youth informal associations, on which people earn, and that earn.

2. The most active informal communities as subjects of economic activity were analysed, which made it possible to come to the conclusion that the "life activity" of the specified communities is predetermined not only by some ideas, views, moods, way of life but also business opportunities, opportunities to make a profit.

3. The results of the research can be used to further study the various aspects of the youth informal environment. In particular, in the context of combating illegal business activities, tax evasion.

\section{References:}

Bashkatov, I. P. (2002). Psikhologiya asotsialno-kriminalnykh grupp podrostkov i molodezhi [Psychology of asocial-criminal groups of teenagers and youth]. M.: Publishing House of Moscow Psycho-Social Institute; Voronezh: Publishing House NPO "MODEK", $416 \mathrm{p}$.

Blyzniuk, I. V. (2010). Suchasnyi molodizhnyi rukh v Ukraini (1980-ti - 2008): istoriohrafiia: avtoref. dys. na zdobuttia nauk. stupenia kand. ist. nauk: spets. 07.00 .06 «Istoriohrafiia, dzhereloznavstvo ta spetsialni istorychni dystsypliny» [Contemporary youth movement in Ukraine (1980s - 2008): historiography: extended thesis abstract for Cand. Sc. (History): 07.00.06 "Historiography, Source Studies and Special Historical Disciplines"]. Pereiaslav-Khmelnytskyi, $20 \mathrm{p}$. 
Boiko, O. (2001). Predtecha rukhu: neformalni orhanizatsii yak faktor hromadsko-politychnoho zhyttia Ukrainy u period perebudovy [Forerunner of movement: informal organizations as a factor of public-political life of Ukraine during the period of perestroika]. Liudyna i Polityka, № 1: 44-57.

Boiarov, V. I. (2014). Kryminalistychna kharakterystyka kryminalno-karanykh proiaviv ekstremizmu [Forensic characteristics of criminal punitive manifestations of extremism]. Journal of the Academy of Advocacy of Ukraine. Vol. 7, № 4 (25), p.3-8. Retrieved from: http://nbuv.gov.ua/UJRN/Chaau_2014_7_4_2

Vasylchuk, Ye .O. (2016). Molodizhnyi politychnyi radykalizm ta ekstremizm u suchasnii Ukraini: avtoref. dys. na zdobuttia nauk. stupenia dokt. polit. nauk: spets. 23.00.03 «Politychna kultura ta ideolohiia» [Youth political radicalism and extremism in modern Ukraine: extended thesis abstract for Cand. Sc. (Political Science): 23.00.03 "Political Culture and Ideology"]. Kyiv, 41 p.

Gilinskii, Ya. I. (2010). Prestupnost nesovershennoletnikh: kriminologicheskiy analiz [Crime of minors: criminological analysis]. Kriminalist, № 2(7): 84-90.

Ershov, V. A. (2006). Metodika rassledovaniya prestupleniy protiv zhizni i zdorov'ya grazhdan, sovershaemykh chlenami neformalnykh grupp (dvizheniy): avtoref. dis. na soiskanie uchen. stepeni kand. yurid. nauk: spets.12.00.09 «Ugolovnyy protsess, kriminalistika i sudebnaya ekspertiza; operativno-rozysknaya deyatelnost» [The methodology for investigating crimes against the life and health of citizens committed by members of informal groups (movements): extended thesis abstract for Cand. Sc. (Jurisprudence): 12.00.09 "Criminal Process, Forensic Science and Forensic Examination; Operatively-Search Activity”]. Vladivostok, 18 p.

King, J. (2010). Skinheads: [novel]. M.: AST, Astrel, 415 p.

Levikova, S. I. (2002). Fenomen molodezhnoy subkultury (sotsialno-filosofskiy aspekt): dissertatsiya ... doktora filosofskikh nauk: 09.00.11 [The phenomenon of youth subculture (socio-philosophical aspect): thesis for a Doctor's of Philosophy degree: 09.00.11]. Moscow, 358 p.

Lisovets, O. V. (2011). Teoriia i metodyka roboty z dytiachymy ta molodizhnymy orhanizatsiiamy Ukrainy [Theory and methodology of work with children's and youth organizations of Ukraine]. K.: PC "Akademiia", 256 p.

Maugham, S. (2010). Of Human Bondage: [novel: translated from Eng.]. M.: AST: Astrel, 685 p.

Rybakova, S. S. Tsennostnye orientatsii predstaviteley molodezhnykh subkul'tur v sovremennom obshchestve [Value orientations of representatives of youth subcultures in modern society]. Electronic resource: https://www.scienceforum.ru/2016/2152/17710.

Soroka, S. V. (2006). Suspilno-politychna diialnist neformalnykh obiednan molodi Ukrainy u 1953-1991 rokakh: avtoref. dys. na zdobuttia nauk. stupenia kand. polit. nauk: spets. 23.00 .02 «Politychni instytuty ta protsesy» [Socio-political activity of informal associations of youth of Ukraine in 1953-1991: extended thesis abstract for Cand. Sc. (Political Science): 23.00.02 "Political Institutions and Processes"]. Mykolaiv, 20 p.

Cherneta, S. Yu. (2005). Orhanizatsiino-pedahohichni umovy sotsializatsii pidlitkiv u neformalnykh molodizhnykh obiednanniakh: avtoref. dys. na zdobuttia nauk. stupenia kand. ped. nauk: spets. 13.00 .05 «Sotsialna pedahohika» [Organizational-pedagogical conditions of socialization of adolescents in informal youth associations: extended thesis abstract for Cand. Sc. (Pedagogical Science): 13.00.05 "Social Pedagogy"]. Kyiv, 18 p. 